DOI 10.37882/2223-2982.2021.05-2.12

\title{
ПРЕДСТАВЛЕНИЯ О ВОСПИТАНИИ ДЕТЕЙ В РУССКОЙ НАРОДНОЙ ПЕДАГОГИКЕ
}

\section{IDEAS ABOUT THE UPBRINGING OF CHILDREN IN RUSSIAN FOLK PEDAGOGY}

A. Izmailova

Summary: The article considers the ideas about the initial stage of education, based simultaneously on the pagan and Orthodox traditions of Russian folk pedagogy. Education is aimed at the formation of moral and physical perfection. The undesirable methods based on the Old Testament tradition were gradually replaced by the more humane methods of education offered by the New Testament tradition. Numerous folklore works as a means of education in Russian folk pedagogy adapted the biblical ideas to the domestic conditions and offered parents answers to the pressing problems of raising children. Children are perceived in Russian folk pedagogy as a gift from God, and their upbringing is considered the primary duty of parents. The very process of raising children should begin with the birth of their mother. Examples of the use of methods and means of Russian folk pedagogy in the process of raising children are given.

Keywords: the idea of the perfect man in Russian folk pedagogy, education and training in Russian folk pedagogy, pagan and Orthodox traditions of Russian folk pedagogy, methods and means of Russian folk pedagogy, virtues and vices in moral education.

\author{
Измайлова Алла Борисовна \\ К.п.н., дочент, Владимирский государственный \\ университет имени А.Г. и Н.Г. Столетовых \\ aismylove@yandex.ru
}

Аннотация: В статье рассматриваются представления 0 первоначальном этапе воспитания, базирующиеся одновременно на языческой и православной традициях русской народной педагогики. Воспитание направлено на формирование нравственного и физического совершенства. Нежелательные методы, основанные на ветхозаветной традиции, постепенно были вытеснены предлагаемыми новозаветной традицией более гуманными методами воспитания. Многочисленные фольклорные произведения как средства воспитания в русской народной педагогике адаптировали библейские идеи к отечественным условиям и предлагали родителям ответы на насущные проблемы воспитания детей. Дети воспринимаются в русской народной педагогике как Божий дар, а их воспитание считается первостепенным долгом родителей. Сам процесс воспитания детей следует начинать с момента рождения их матери. Приведены примеры использования методов и средств русской народной педагогики в процессе воспитания детей.

Ключевые слова: идея совершенного человека в русской народной педагогике, воспитание и обучение в русской народной педагогике, языческая и православная традиции русской народной педагогики, методы и средства русской народной педагогики, добродетели и пороки в нравственном воспитании.

необходимых в его среде знаний, умений и навыков.

питании детей зафиксированы в многочисленных произведениях русской народной духовной и материальной культуры. При этом следует учитывать, что русская народная педагогика базируется одновременно на древней языческой и более поздней православной традициях, что подтверждается ее источниками.

Образование личности в русской народной педагогике имеет теоретическое обоснование (идея совершенного человека, триада «Истина - Добро - Красота», четкое разграничение добродетелей и пороков) и практические подходы (существующие в российском обществе традиции и нормы поведения). «Идеалы совершенной личности у разных народов очень близки друг другу. Они включают ум, красоту, нравственные достоинства, физическую силу (здоровье), выносливость» [1, с. 20].

Процессы воспитания и обучения в русской народной педагогике понимаются следующим образом. Воспитание должно заложить в воспитуемом стремление к нравственному и физическому совершенству, а процесс обучения направлен на приобретение человеком всех
Старинное значение слова «воспитание» означало «вскормление, старание о научении и образовании детей» $[2$, с. 96]. Исследователи подчеркивают, что «до XVI в. слово "воспитати" имело чисто житейский смысл"вскормить". Затем оно постепенно приобрело педагогическое значение. Кстати заметим, что "Поучение Златоуста" в сборнике XVI в. называлось "О вскормлении детей", а в начале XVII в. - уже "О воспитании чад". В "Домострое" термин "воспитати" уже употребляется в новом значении ("Како детей своих воспитати во всяком наказании и страсе Божии") [3, с. 58-59].

К достижению духовного и физического совершенства и гармоничности воспитатель ведет воспитуемого, руководствуясь принципом русской народной педагогики «Делай, как я». Очевидно, что в таких условиях воспитатель сам должен обладать гармонией и совершенством души и тела.

Воспитание нового члена семьи и общества рассматривается воспитателями как долг и радость. Вос- 
питатели должны были ребенка кормить, укачивать, если плохо спал, молиться о здравии и лечить, если был нездоров (мать, как правило, обладала базовыми знаниями для лечения ребенка, и только в более сложных случаях обращалась к знахарям), заботиться о его развитии и воспитании.

Этот повседневный труд воспитателя в русской народной педагогике обеспечивал не только уход за ребенком, но его воспитание, о чем писал еще В.Г. Белинский: «Воспитывать не значит только выкармливать и вынянчивать (первое может сделать корова или коза, а второе нянька), но и дать направление сердцу и уму» [Цит. по: 4, с. 99].

Воспитание ребенка считается неотъемлемым долгом родителей. Такой подход был определен еще спартанским законодателем Ликургом, «постановившим, чтобы за известные проступки сыновей и дочерей были наказываемы отиы и матери. Почему? Потому что родители добрым воспитанием могли и должны были предотвратить проступки детей своих» [5, с. 129].

Идея совершенного человека в языческой традиции русской народной педагогики определяла цель жизни мужчины как последовательную совокупность постепенно усложняющихся задач: «Посадить дерево, nостроить дом, вырастить сына» (сейчас нередко добавляют 4 задачу - «написать книгу»). В православной традиции русской народной педагогики цель жизни формулируется как «спасение души», поэтому перечисленные выше задачи становятся лишь средствами к ее достижению.

Воспитание достойных детей, как уже отмечалось, является не только обязанностью родителя, но и радостью, поскольку именно дети делают жизнь человека счастливой: «Жизнь мою счастливят дети» [6, т. 4, с. 372], «Детки мои - порадованье мое» [6, т. 3, с. 311] и др.

Достойные «Родители любят детей свочх, желают им добра, болеют за них сердчем» [6, т. 2, с. 282], «Дети-то во благо, к счастью. Дети - благодать Божья» [7, с. 13].

К началу XX в. представления о воспитании в русской народной педагогике в значительной степени базировались на Новом завете: «Отцы, не раздражайте чад своих, но воспитывайте их в учении и наставлении Господнем» [Eø.: 6, 4]. Эта цитата рекомендует применять методы из группы методов стимулирования поведения родителей - совет, наставление, предупреждение [8, с. 10].

Такой педагогический подход был существенным продвижением вперед по сравнению с рекомендациями «Домостроя», основанными на Ветхом завете: «Наказывай сына своего, доколе есть надежда, и не возмущайся криком его» [Пр.: 19, 18], «Розга и обличение дают мудрость; но отрок, оставленный в небрежении, делает стыд своей матери» [Пр.: 29, 15] и др.

Здесь тоже предлагаются методы из группы методов стимулирования поведения, но это методы приказа и требования [8, с. 10]. Рекомендуются к применению и нежелательные методы физического наказания [9] - побои (из группы методов наказания [8, с. 10]) с целью причинить боль ребенку.

Осознание необходимости воспитания детей в любви и согласии постепенно завоевывало всё большее количество приверженцев среди родителей - субъектов воспитательного процесса, хотя часть родителей, оставаясь его объектами, продолжала придерживаться требований Ветхого завета.

Воспитание достойного человека всегда требовало много труда, что отмечают многие русские народные пословицы и поговорки. Эти пословицы и поговорки являются средствами реализации методов стимулирования поведения в русской народной педагогике. Например, таких методов, как наставление, совет, упрек и др. [8, с. 10], обращенных к начинающим воспитателям: «Не устанешь детей рожаючи, устанешь на место сажаючи», «Детушек воспитать - не курочек пересчитать», «Умел детей родить, умей и научить» [10, т. 1, с. 298], «Умела народить, умей и споводить (т.е. воспитать, выкормить и научить добру)» [6, т. 4, с. 293] и др.

Для того чтобы правильно воспитать ребенка, русская народная педагогика советовала воспитателям не спускать с него глаз, особенно в младенческий период: «Ребенок всегда у меня на глазах (или под глазами)» [6, т. 1, c. 354].

В известной русской народной сказке «Гуси-лебеди» юная воспитательница оставила маленького брата без присмотра, и он был унесен стаей гусей-лебедей к Бабе Яге.

Воспитание ребенка добрым человеком (т.е. хорошим [2, с. 147]) в русской народной педагогике считалось делом более значимым, чем рождение его на свет: «Не mom отеи, мать, кто родил, а тот, кто вспоил, вскормил да добру научил» [10, т. 1, с. 300]. Эту пословицу также следует отнести к средствам реализации метода наставления в русской народной педагогике.

О проблемах и неудачах в воспитании детей говорят многие пословицы и поговорки, являющиеся средствами реализации методов из группы методов стимулирования поведения в русской народной педагогике. Это следующие методы: наставление («Дети отиу-матери больки (близки к сердцу, обидно, досадно за них)», «Огонь - горячо, а дитя - болячо» [6, т. 1, с. 112], «Свое 
детище - вар у сердиа (болячо, болько)» [6, т. 1, с. 165], «Детки - кручина родительская» [6, т. 2, с. 204]), упрек («Ох, уж мне эти дети!» [6, т. 2, с. 774], «Ну, уродилось дитятко!» [6, т. 4, с. 508], «Дети родились, да никуда не годились» $[6$, т. 1, с. 365]), предупреждение («У кого детки, у того и бедки» [6, т. 4, с. 456], «Маленькие детки, маленькие бедки, а вырастут велики - будут большие» [6, т. 1, с. 437]), объяснение («Забота по детям крушит меня» [6, т. 2, с. 204], «Дети его удручают» [6, т. 4, с. 475]) и др.

Процесс воспитания детей неразрывно связан с беспокойством и трудами родителей. Не случайно, говорили, что «Без детей гребты (забота, опасенье, раздумье, попеченье) не знаешь» [6, т. 1, с. 391] и др.

Однако родители не жалели сил и времени для доброго воспитания младенца. Особенно поэтично об этом рассказывается в русских народных сказках: «Был у царя с царицей сынок Павел-царевич - единое дитятко. Любили они его, холили, ветру на него дунуть не давали» $[11$, с. 203].

Зато, если удавалось хорошо воспитать детей, родители могли считать, что важная их обязанность на земле выполнена. Многие пословицы и поговорки являются средствами реализации метода похвалы родителей (из группы методов поощрения в русской народной педагогике [8, с. 10]): «Добрый сын всему свету завидище», «Дочерьми красуются, сыновьями в почете живут» [10, т. 1, с. 299], «Кто красен дочерьми, да сынами в почете, тот в благодати» [6, т. 3, с. 371], «Сынами славен, дочерьми честен», «Богат сыновьями, славен дочерьми» [6, т. 4, с. 375] и др.

Во многих русских народных пословицах и поговорках подчеркиваются те качества, совокупность которых образует идею совершенного человека и упомянутую триаду. Это доброта (слово «доброта» очень многозначно в церковнославянском языке: «привлекательная наружность, красота, изящество, внутреннее совершенство, доброта, величие, слава, добродушие, благость, милосердие» и др. [2, с. 147-148]), а также и другие добродетели в православной традиции русской народной педагогики.

Русская народная педагогика советовала родителям много трудиться для воспитания ребенка, чтобы за него им не было бы впоследствии стыдно. Объем прилагаемых усилий воспитателей зависит от склонностей новорожденного младенца, потенциал которого пока неизвестен («Ребенок - почка, а цветок неведом!» [6, т. 3, с. 372]).

В соответствии с традицией русской народной педагогики родители, которым удалось воспитать достойных детей, смиренно говорили: «Господь очадил нас благодатно (много удатных детей)» [6, т. 2, с. 776]. Тем самым, родители подчеркивали, что они, прилагая свои силы и возможности в деле воспитания детей, всецело полагались на помощь Божью.

О противоположных результатах воспитания говорят фольклорные источники назидательного характера, например: «Некогда же велицы пианицы и блудники бывают, / Понос и укор отиу и матери приносят» [12, с. 37], «Отиу-матери бесчестье - роду-племени покор» [10, т. 1, с. 300] и др.

Те же мысли о невоспитанных детях выражаются в многочисленных пословицах и поговорках: «Неудатный сынища отиу-матери покор» [6, т. 4, с. 375], «Детки хороши - отиу-матери венец; худы - отиу-матери конец» [6, т. 1, с. 331], «Блудный сын - ранняя могила отиу» [6, т. 1, с. 99], «Малый вырастет, всё выместит (говорится о дурном воспитании)» [6, т. 1, с. 310], «Выросту, так вымещу» [6, т. 1, с. 301], «Не досади малому, не попомнит старый» [6, т. 2, с. 293] и др.

Эти пословицы и поговорки являются средствами реализации методов стимулирования в русской народной педагогике (наставление, предупреждение, предсказание и др.), адресованных не только неуспешным родителям, но и тем, кому родительская миссия еще предстоит.

Неправильное воспитание детей традиционно воспринималось в русской народной педагогике как отклонение от пути истины, поэтому плохо воспитанного ребенка называли также «непутным»: «У него сынишка такой непутный вышел, что избави Бог» [6, т. 2, с. 532].

Православная традиция русской народной педагогики полностью возлагает на родителей ответственность за дурное воспитание детей: «Когда тяжко вам становится оттого, что творят ваши дети, тогда вы плачете, тогда вы Богу молитесь, чтобы Он помог вам. / А молитва ваша остается бесплодной. Почему же бесплодной? / Потому что нельзя на Бога возлагать своих собственных обязанностей, потому что вы сами должны были заботиться о детях ваших и воспитывать их, не ждать, что за вашим нерадением за вас исполнит это Бог. / Если слуга ваш не радеет о своем долге и ждет, чтобы вы сами исполнили его, то разве вы станете работать за него, разве не разгневаетесь на нерадивого слугу? / Что же вы хотите от Бога, если сами не радеете о детях ваших? / Св. Иоанн Златоустый сказал страшные слова о тех, которые не воспитывают детей своих: / "Родители, которые пренебрегают воспитывать детей своих по-христиански, беззаконнее детоубийи, ибо детоубийцы тело от души разлучили, а они душу и тело ввергают в геенну огненную"» [5, с. 197].

К педагогически неуспешным родителям русская народная педагогика применяла метод упрека: «Нарожать 
нарожала, а научить не научила», «Ни себе на радость, ни людям на послугу (нарожал)» [10, т. 1, с. 300] и др.

Русской народной педагогикой давно была подмечена такая закономерность: каковы родители, таковы и дети («У доброго батьки добры и дитятки» [10, т. 1, с. 298], «Яблочко от яблоньки недалеко откатывается» [6, т. 4, с. 671], «Родители трудолюбивы, и дети не ленивы» $[14$, с. 184] и др.).

Позднее на этот счет появилась и такая поговорка, близкая по смыслу: «Om осинки не родятся апельсинки». Однако если предыдущие пословицы говорят, в основном, об успешных родителях, то эта поговорка - о неуспешных. Появление поговорки о неуспешных родителях можно объяснить увеличением негативных результатов воспитания в современных условиях.

Тем самым, в русской народной педагогике было принято искать причину недостатков характера и поведения человека в плохом воспитании и неблагополучии родительской семьи. К таким родителям применяли метод насмешки, реализующийся через такую пословицу: «Наделил Бог детками: день в кабаке, а ночь по клетям (т.е. воруют. - А.И.)!» [6, т. 2, с. 121].

Русская народная педагогика целиком возлагала ответственность за воспитание детей на родителей, не принимая во внимание никакие неблагоприятные влияния окружающей среды.

Важным является определение времени начала воспитания ребенка.

В этой связи известна восточная притча о молодой матери, пришедшей к мудрецу с вопросом, когда ей начинать воспитывать новорожденного ребенка. Мудрец ответил, что она опоздала с воспитанием на девять месяцев.

В русской народной педагогике считалось, что процесс воспитания ребенка следует начинать еще раньше, с того дня, когда сама его мать появилась на свет. Хотя процесс воспитания будущих детей этой девочки идет пока опосредованно, но в нем она осознает свое предназначение как будущей матери. В русской народной педагогике существует убеждение, что если благоприятное время для воспитания будущей матери и хозяйки было упущено, то восполнить это будет почти невозможно.

Приведем такое наблюдение о воспитании девочек: «СКлонность к материнству всасывается девочкой с молоком матери. С самого юного возраста девочки начинают играть в куклы, нянчат их, челуют, наказывают и дают им наставления, слышанные самими от матерей. Девочки страстно привязываются к своим куклам и готовы мужественно защищать их от нападе- ний шалунов братишек. Эта любовь к детям, имеющая корни еще в раннем детстве, с течением времени развивается» $[15$, с. 577-578].

От игр с куклами девочка закономерно переходила к воспитанию младших братьев и сестер, приобретая необходимые для будущей матери практические умения и навыки.

На воспитание девочки как будущей матери воздействовало и созерцание икон Богоматери, которые рассматриваются в православной традиции русской народной педагогики как средство воспитания. Эти иконы, представляющие собой образцы идеальной материнской любви и воплощения идеи совершенного человека, украшали божницу в русских домах и всегда были перед глазами у детей. Педагогическое воздействие образа Богоматери состоит в том, что на иконах очевидна гармония взаимопонимания, взаимной любви, ласки и нежности, когда Мать и Сын склоняются друг к другу.

На многих иконах Младенец прижимается щечкой к лицу Божией Матери (иконы Божией Матери «Владимирская», «Донская», «Не сгоревшая во время пожара», «Почаевская», «Умиление Белозерская» и др.), прикасается ручками к лицу Богоматери (иконы Божией Матери «Умиление», «Словенская», «Ярославская», «Яхромская» и др.), обвивает рукой ее шею (иконы Божией Матери «Елецкая», «Толгская», «Феодоровская» и др.), играет с Богоматерью (икона Божией Матери «Взыграние Младенца»), а Богоматерь прижимает Его к своей груди, бережно поддерживает и нежно ласкает [16].

Внимательно рассматривая эти изображения Божией Матери и Младенца, девочка с самого детства усваивала эти исполненные нежности и любви позы и жесты и, став матерью, именно так ласкала собственное дитя.

Между матерью и новорожденным ребенком гармония легко устанавливается, потому что он безгранично ей доверяет. Суть материнского воспитания в русской народной педагогике состоит в том, чтобы не разрушить существовавшую изначально гармонию между матерью и подросшим ребенком. Для достижения этой цели мать всегда должна быть нравственной в отношениях с детьми.

Непосредственный активный процесс воспитания ребенка следует начинать как можно раньше, учитывая то, что личность ребенка формируется еще до его рождения. Если беременная женщина отклоняется от идеи совершенного человека, ее родившийся ребенок будет ей в этом подражать.

Тем более то, что закладывается с первых мгновений жизни, остается с человеком на всю жизнь, о чем говорит пословица: «Каков в колыбельку, таков и в могилку» 
[6, т. 2, с. 144]. Это означает, что исправить укоренившиеся пороки практически невозможно, и потому заниматься устранением их начальных проявлений следует еще с колыбельного периода жизни ребенка.

Русская народная педагогика применяет к родителям, опоздавшим с воспитанием ребенка, методы насмешки и упрека: «Его поздно учить: распашонка на нем уже не сойдется» [10, т. 1, с. 280], «Не научили, когда поnерек лавки ложился; а во всю вытянулся, так не научишь» $[10$, т. 1, с. 300].

В первой пословице начало воспитания указывается косвенным образом, через одежду, которую носит только новорожденный (распашонка).

Во второй пословице - через рост новорожденного ребенка, который совпадает с шириной лавки в крестьянской избе (около 50 см). К этой пословице в русской народной педагогике дается такой комментарий: «Учи дитя, пока поперек лавки лежит. А как на лавке повернулся дитя, учить уже поздно. Лавки деревенские, пока так поперек лежит, на лавке умещается, в это время учи, а как уже не стал умещаться, так уже поздно учить -у него свое сознание появилось» [7, с. 330].

В русской народной педагогике дети воспринимаются как дар Божий: «дети составляют благословение Божие и выражают собою присутствие Св. Духа в семье, они ее опора и с4астье» [17, с. 427].

О рождении ребенка говорится в такой, например, пословице: «У всякого первенец родится: во лбу светлый месяи, за ушами ясны звезды» [6, т. 3, с. 30-31], а также и в сказке: «У всякого свой сын по локоть в золоте, по пояс в серебре, во лбу ясный месяц, в затылке часты звезды» $[6$, т. 2, с. 264].

Такие средства русской народной педагогики могли служить для реализации методов насмешки и упрека, если родители переоценивали качества своего ребенка.

Неадекватные представления некоторых родителей о своих детях иллюстрирует притча «Орел и Сова» как средство русской народной педагогики (педагогический анализ этой притчи был нами уже ранее выполнен [18]). В этой притче Сова попросила Орла не трогать ее птенцов. Когда Орел спросил, как ему узнать детей Совы, она отвечала: «Как моих не узнать: краше их во всем лесу nтичек нет» [11, с. 92]. Поиски добычи закончились тем, что Орел съел совят, которые показались ему самыми безобразными птенцами в лесу. Однако и после этого Сова продолжала утверждать, что ее дети были самые красивые.

С помощью этой притчи как средства русской народ- ной педагогики родителям подавался совет более взвешенно относиться к физическим и нравственным качествам своих детей. Адекватное восприятие собственных детей позволит родителям оказывать педагогически целесообразное воспитательное воздействие.

Зарождение семьи в русской народной педагогике начинается только с рождения ребенка. Новорожденного ребенка окружают любовь и забота всех членов семьи, его называют ласковыми именами, которые дополняют, а иногда и заменяют его крестное имя.

Как известно, «У любимого дитятки много имен». В русской народной педагогике существуют многочисленные наименования ребенка, подчеркивающие такие его особенности, как малые рост и возраст, а также выражающие любовь матери. Широко известно ласковое обращение матери к младенцу: «Дитятко мое ненаглядное!» $[6$, т. 2, с. 523].

Из других наименований младенца, также выражающих отношение к нему в русской народной педагогике, приведем следующие: «крохотка, крошечка - крошка, малютка. Мой крохотка уснул», «крошка, крошутка - малютка, малыш, малый ребенок» [6, т. 2, с. 199], «малыш, малышка, малышонок, маленка - ребенок, дитя, мальчик и девочка», «малютка, малюточка - младенец, малый ребенок, дитя» [6, т. 2, с. 294], «махоночка - девчонка, дитя» 6 , т. 2, с. 309], «мильча (обращаясь к ребенку)» [6, т. 2, с. 326], «наперсток - любимое дитятко» [6, т. 2, с. 449], «оглядыш мой - за кем я гляжу, ухаживаю, воспитанник, воскормленник» [6, т. 2, с. 572], «ляля, лялька - дитя, дитятко, ребеночек, младенец» [6, т. 2, с. 286] и др.

Интересно отметить, что другое значение слова «ляля» - игрушка [Там же]. Так выражалось восхищение красотой ребенка, который воспринимался как большая кукла, игрушка.

Однако при благожелательном отношении всей семьи к младенцу, мать никто не мог ему заменить. Это поэтически отмечается такими пословицами: «Птица радуется весне, а ребенок матери» [10, т. 1, с. 302], «При солнце тепло, а при матери добро» [6, т. 1, с. 443] и др.

Несравнимость родной матери с другими воспитателями отражается и в такой пословице: «Бог до людей, что мать до детей (добра)» [6, т. 2, с. 307].

Кроме того, в русской народной педагогике считалось, что у каждого человека три матери: «Первая мать Пресвятая Богородица, / Вторая мать - сыра земля, / Третья мать, коя скорбь приняла» [19, с. 11].

Сближение этих образов подтверждалось и народными воззрениями, что женщина должна рожать еже- 
годно, как это делает Мать Сыра Земля.

Взаимосвязь и взаимозависимость всех этих трех материнских образов в народном сознании приводили к тому, что каждый русский человек считал своим долгом глубоко почитать их всех. Все три образа символизировали Заступницу, Молитвенницу, Помощницу всех детей и людей.

Именно на мать приходились основные труды, связанные с воспитанием ребенка, не случайно в народной песне поется: «Покуль мене мати выховала («Выховывать, выховать - выберечь, вспоить и вскормить, взростить, выхолить, выростить, воспитать» [6, т. 1, с. 325]), сорок ясных свечей спалила» [Там же].

Как уже отмечалось, обстоятельность подхода русской народной педагогики к воспитанию требовала отнесения начала педагогического воздействия на ребенка задолго до его рождения, а именно: к моменту рождения его матери. Многолетний путь подготовки девушки к осуществлению главной своей миссии на земле приводил к тому, что она весь мир воспринимала, с точки зрения материнства. Всё, что окружало девочку, девушку, молодую женщину, оценивалось ею, исходя из того, насколько это будет полезно ее будущим детям. Если планируемые действие или поступок могли быть неполезны, она от них отказывалась.

С того момента, как женщина узнавала о наступлении беременности, изменялись внешняя линия ее поведения и внутреннее состояние ее души. Глубокая религиозность заставляла русскую женщину-мать принимать зарождение в себе новой жизни как дар Божий. Ради благополучия ребенка будущая мать каждый свой поступок, слово и даже мысль сверяла с пришедшими из глубины веков заветами предков. Такая строгая система регламентации поведения беременной женщины помогала выносить здорового ребенка, обеспечивала душевное спокойствие, уравновешенность и твердую уверенность в благополучном исходе беременности и родов и в рождении благополучного ребенка.

Таким образом, подводя некоторые итоги рассмотрения представлений о воспитании детей в русской народной педагогике, можно сделать следующие выводы. По имеющимся источникам русской народной педагогики, следует отметить, что в народном сознании существуют глубоко укоренившиеся представления о том, как родителям следует заниматься воспитанием ребенка. Эти представления основаны на взаимодействии библейских воззрений на родительский долг с их народной интерпретацией, зафиксированной в многочисленных произведениях русского фольклора. В православной традиции русской народной педагогики постепенно происходил отход от ветхозаветной традиции, в которой воспитатели выступают преимущественно объектами процесса воспитания, к более гуманной новозаветной традиции. Основанный на отечественных реалиях фольклор дополняет и развивает библейские традиции воспитания, помогая родителям найти верные решения в сложных педагогических ситуациях воспитания и обучения ребенка. Многочисленные произведения русского фольклора и одновременно средства русской народной педагогики обеспечивают эффективную реализацию оптимальных методов воздействия на воспитуемых.

\section{ЛИТЕРАТУРА}

1. Волков, Г.Н. Народная педагогика / Г.Н. Волков // Российская педагогическая энциклопедия: в 2 т. - М., 1993. - Т. 2. - С. $20-21$.

2. Полный церковнославянский словарь (с внесением в него важнейших древнерусских слов и выражений) / сост. протоиерей Г. Дьяченко. - Репринт. воспроизвед. изд. 1900 г. - М., 1993. - 1120 с.

3. Комаровский, Б.Б. Русская педагогическая терминология: теория и история / Б.Б. Комаровский. - М., 1969. - 311 с.

4. Умом и сердцем: Мысли о воспитании / сост. Н.И. Монахов. - М., 1982. - 383 с.

5. Опыты православной педагогики / сост. А. Стрижев, С. Фомин // Литературная учеба. - 1993. - № 5-6. - С. 110-202.

6. Даль, В.И. Толковый словарь живого великорусского языка: в 4 т. / В.И. Даль. - Репринт. воспроизвед. изд. 1880-1882 гг. - М., $1978-1980$.

7. Науменко, Г.М. Этнография детства: сб. фольклорных и этнографических материалов / Н.Г. Науменко. - М., 1998. - 390 с.

8. Измайлова, А.Б. Русская народная педагогика (семейная педагогика): программа, материалы к курсу и методические рекомендации / А.Б. Измайлова. - Владимир, 2011. - 48 с.

9. Измайлова, А.Б. Физические наказания в русской народной педагогике / А.Б. Измайлова // Философия и практика ненасилия: материалы XXVI Bсерос. науч.-практ. конференции. - СПб., 21.04.2005. - СПб., 2005. - С. 322-330.

10. Даль, В.И. Пословицы русского народа: в 2 т. / В.И. Даль. - М., 1984.

11. Сказки русского народа / сост. В.А. Гатцук. - М., 1992. -416 С.

12. Флегон, А. За пределами русских словарей / А. Флегон. - Лондон, 1973. - 408 с.

13. Фразеологический словарь русского литературного языка конца XVIII-XX вв. / под ред. А.И. Федорова. - М., 1995. - 608 с.

14. Русские пословицы и поговорки / сост. А.И. Соболев. - М., 1983. - 304 с.

15. Мудрость народная. Жизнь человека в русском фольклоре. - М., 1991. - Вып. 1. Младенчество. Детство. - 589 с.

16. Чудотворные иконы Матери Божией: в 2 т. - Коломна, 1993. 
17. Попов, Г.И. Русская народно-бытовая медицина / Г.И. Попов // Торэн М.Д. Русская народная медицина и психотерапия. - СПб., 1996. - С. $277-420$.

18. Измайлова, А.Б. Представления о сове в русской народной педагогике / А.Б. Измайлова // Science in the modern information society XXIV: Proceedings of the Conference. - North Charleston, 9-10.11.2020. - Morrisville, NC, USA, 2020. - PP. 88-99.

19. Каман, Э. Заметки об источниках русских духовных стихов / Э. Каман // Живая старина. - 1999. - № 2. - С. 10-11.

(с) Измайлова Алла Борисовна (aismylove@yandex.ru).

Журнал «Современная наука: актуальные проблемы теории и практики»

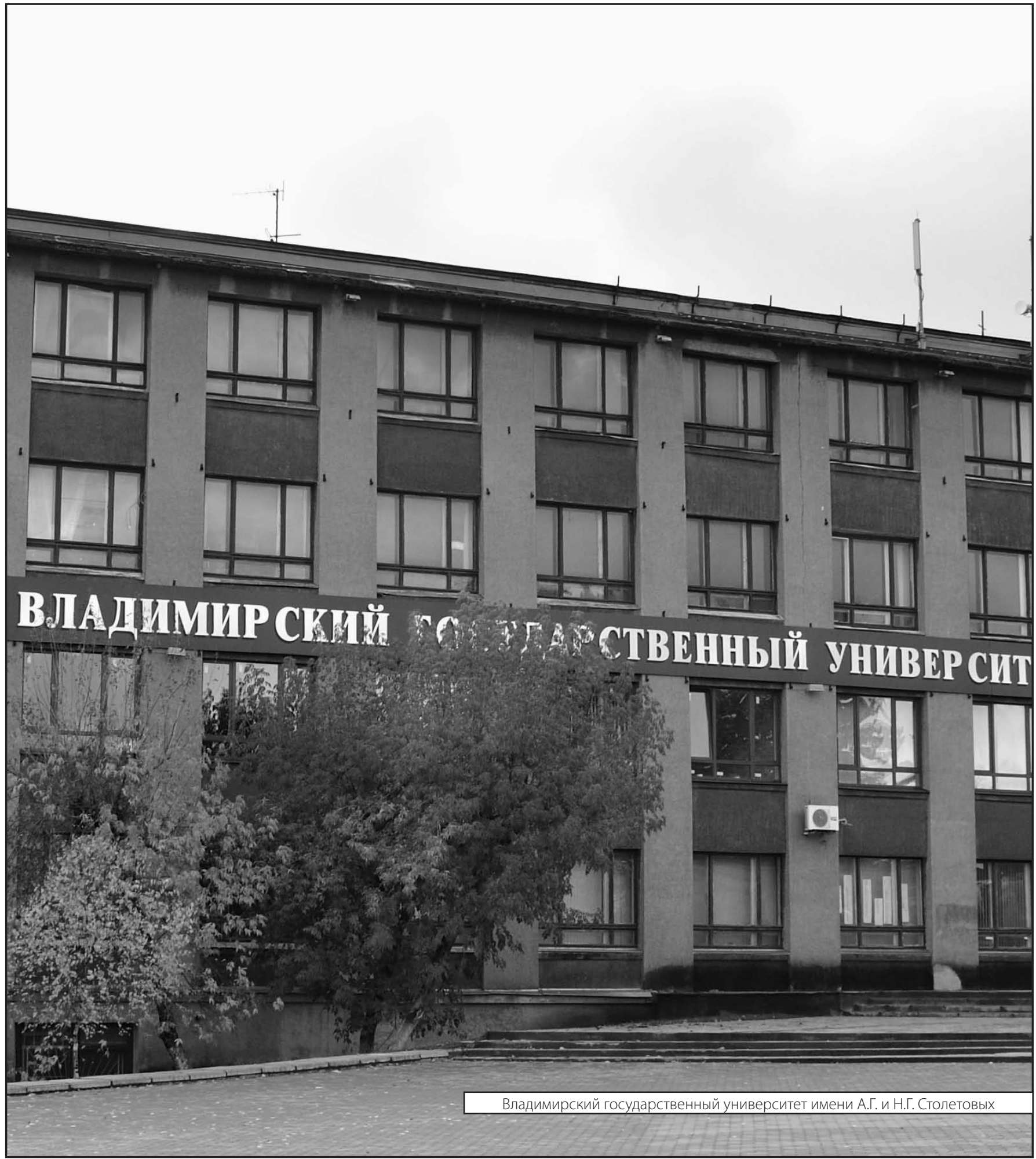

